\title{
THE BODY MOVEMENT AT CARIMBÓ DANCE: A contribution to the Sensory-Motor Development at Physical Education class in Early Childhood Education in Belém (PA)
}

O CORPO EM MOVIMENTO NO CARIMBÓ: uma contribuição no Desenvolvimento Sensório-Motor em Educação Física na Educação Infantil em Belém (PA)

EL CUERPO EN MOVIMIENTO EN CARIMBÓ: una contribución al Desarrollo Sensoriomotor en Educación Física en la Educación Infantil en Belém (PA)

\section{Ana D'Arc Martins de Azevedo}

$\mathrm{PhD}$ in Education (PUC/SP). Adjunct professor at Universidade do Estado do Pará (UEPA). azevedoanadarc@gmail.com.

0000-0003-4240-9579

\section{Camila Rodrigues Neiva \\ Master by the Postgraduate Program in Communication, Languages and Culture - PPGCLC (PPGCLC/UNAMA). camiius.rodrigues@hotmail.com. \\ 0000-0003-3028-7201}

\section{Edgar Monteiro Chagas Junior}

$\mathrm{PhD}$ in Sociology and Anthropology (PPGSA/UFPA). Professor and Researcher at Universidade da Amazônia - UNAMA, where also coordinates the Graduate Program in Communication, Languages and Culture PPGCLC. edgar.chagas@unama.br.

0000-0003-2048-560X

Maria Betânia de Carvalho Fidalgo Arroyo

$\mathrm{PhD}$ by the Graduate Program in Administration (PPAD) at Universidade da Amazônia (UNAMA). Professor and researcher in the Postgraduate Program in Communication, Languages and Culture (PPGCLC) at UNAMA. betania.fidalgo@unama.br.

0000-0002-7745-6394

Mailing address: Universidade da Amazônia (UNAMA). Av. Alcindo Cacela, 287. 66060902 - Belém/PA. Brasil. Fone: (91) 4009-3000.

\section{Introduction}

This article is the result of research carried out in 2019 for the master's degree in Communication, Languages and Culture at the University of the Amazon. It adresses about Carimbó, as a manifestation that involves a complex cultura and that was registered, in 2014, as Brazil's intangible cultural heritage by the Institute of National Historical and Artistic Heritage - IPHAN. This is a cultural event that focuses on music and dance as a ludic-pedagogical instrument which can contribute to the sensory-motor development in Early Childhood Education, notably from Physical Education classes and the contributions that the culture experiences of the body movement in the context of Amazonian forms of expression can bring to the student's training process, thus working with different aspects of human development, such as affective, motor and cognitive.

\author{
Published: 01.01 .2021$.
}

\begin{abstract}
:
This article highlights Carimbó as a symbol of traditional culture and the state of Pará identity, being an instrument to work according to Wallon theory on sensorymotor development. The matter discussed is about to know how Carimbó contributes to students sensory-motor development in Early Childhood Education (toddlers) in Physical Education classes. It's a qualitative participatory observation instrument and an open interview with a teacher and six students. For data analysis, data triangulation was used. As a result, we understand that Carimbó made viable the students sensory-motor development. On this account it was possible to observe the development of the researched aspects.
\end{abstract}

KEYWORDS Carimbó; Sensory-Motor Development; Physical Education. 
It is intended, then, to present Physical Education focused on body culture, starting from the dance, the game, the music of Carimbó for the human development of children in the initial series. We understand, from the references proposed here, that the manifestations of local culture can be an important contributor with regard to the domain of the child's body in the age of one to three years, in order to improve the necessary control of him for the development of any other motor skills, as well as collaborating for intellectual development and critical citizen education in relation to their original place.

According to Caparroz (2007), in the 1980s, during the context of a broad social and political movement in favor of the Brazilian (re) democratization society, a movement was formed, also within the Brazilian Physical Education community, after called the renewal movement, which was characterized by a strong criticism of the role attributed until then to Physical Education in the school curriculum. And it is from there that a radical change occurs in the understanding of the content of the discipline.

Dance, being one of the most essential forms of manifestation and expression of the human movement, is necessary to develop the students' interest, involving them more and more in the cultures of the places. Based on that, it is considered an important modality of the teaching-learning process in school planning, in Physical Education classes, not as a form of mere reproduction of gestures, but as a means of reflection and sensorimotor stimulus of the student, seeking his greater involvement, making it more critical and participative in the socio-cultural context that surrounds it.

Carimbó is a popular music and dance genre from the north of Brazil, whose origin comes from the fusion between indigenous, African and Iberian cultures, confusing even its most native players when asked about its origin. There are few historical records on the trajectory of Carimbó. It is known that the name was given, according to Salles and Salles (1969), through the indigenous percussion instrument, the curimbó, made with an excavated wooden trunk and covered with animal skin.

It is more common in the state's Atlantic area in Pará, however, it is not absent from other regions. It is practiced in the interior of the state, mainly in the months of end and beginning of the year (November, December and January), and in the capital, it is more present in the June season. In another way, it happens in meetings, birthdays and various celebrations that do not depend on a fixed annual calendar. It is characterized by its communicational function and historically linked to the religious events of Catholic Church patron saints (or not) in the cities.

Carimbó works in School Physical Education in a different way, seeking practical experiences based on ethical, moral, civic and social values. However, the influence of 
competitive actions and the sporting process in the school environment of the child's body development is evident.

The National Common Curricular Base - BNCC, says that at that age, from one to three years, specifically one year and seven months to three years and eleven months, aims at learning and developing, moving your body in space, orienting themselves by notions, such as front, back, top, bottom, inside, outside, etc., when engaging in games and activities of different natures (BRASIL, 2016). Thus, when approaching the learning experiences at BNCC, very young children, who are considered to be from one to three years old, appropriate the space around them with interest, whether in their classroom or in the outdoor space. They like to play next to each other and are interested in the objects, people and actions around them.

According to the Law of Guidelines and Bases in Education (LDB) 9394/96, Early Childhood Education aims to provide the child's physical, emotional, cognitive and social development. In addition, Basei (2008) explains that it is necessary the Kindergaten school allows the child to have access to elements of universal culture and nature, being able to exchange experiences with other children and the teacher is a mediator, making the school a socio-educational space. And in that school age, there is a need for a proper psychopedagogical environment, capable of stimulating the child's sensory-motor development and the cultural folds of his socialization process.

For Wallon (1975), the child's development happens naturally in the midst of his socio-cultural environment, that is, the development process is treated in an integrated way, in which the reality that is being woven is not only in the individual, but in social and cultural relationships that have historically been situated in society (in their spaces and institutions).

Carimbó, considered a regional Pará rhythm, is usually approached in some way within the environment of state schools, which led us to the interest of deepening studies in relation to the different ramifications of knowledge that this cultural manifestation provides according to the contents of Physical Education in the early grades. In general, it is understood that it can assist, in a different way, in the human development of each student, working with rhythm, flexibility, musicality, motor, cognitive and social coordination. It is known that children in Early Childhood Education, who are in the group of one to three years, need stimuli for their development. And it is important to emphasize that much of the specialized literature asserts that the educational process should always promote socializing activities to trigger the child's learning. 
According to the arguments above, we started with a research question: how does Carimbó contribute to the sensory-motor development of students in Early Childhood Education (Kindergarten) in Physical Education classes at a school in Belém do Pará?

From this, specifically, we invetigate: a) the ways that Carimbó, while dancing, contributes to the affectivity development in the student; b) The skills of Carimbó dance that can be used for cognitive development; c) the ways that Carimbó contributes to motor coordination.

\section{The Moving Body in Carimbó}

Among the diverse Brazilian folk dances, Carimbó is characteristic from the country north region, more specifically from Pará. It has origins in the syncretism between black, indigenous and Portuguese cultures (GABBAY, 2010).

As a symbol of traditional culture and Pará identity, Carimbó is not only focused on dancing and music. According to Figueiredo and Bogéa (2015, p. 82), it also "involves ways of living (cultural manifestation and social movement) and ways of doing (artistic expression and the production chain)". It is highlighted throughout the Pará state, with greater evidence in some regions: Salgado Region, Northeast Coast of the State, Metropolitan Region of Belém, in the Region of Guamá and in Marajó Island.

Carimbó is found in almost all regions of Pará, and for more than two centuries it has maintained its tradition along with the process of reinvention. It shows as features, instruments, dance and music, resulting from indigenous, black and Iberian cultural influences. The "carimbozeiros" organization and social reproduction, in reference to the daily work and religious celebrations, form the striking structure of its configuration. It focuses on leisure, religiosity, artistic expression, public and family parties (FIGUEIREDO; BOGÉA, 2015).

Carimbó, as a form of expression, manifests itself throughout the year, and its history goes back to the 17th century, in the Amazon region, which corresponds to current Pará. According to the existing records, the drumming that gave rise, among others rhythms, to Carimbó, were brought to Brazil by black African slaves and incorporated indigenous and Iberian influences, giving rise to a singular manifestation, represented by groups that spread across several cities (FIGUEIREDO; BOGÉA, 2015). For Souza (2011), it was with the arrival of blacks in the region that Carimbó gained new characteristics; it became a faster pace, with a more agitated dance and full of swaying. Thus, it became known as "clean banks", because nobody could stand still at this pace.

The name Carimbó came from the indigenous percussion instrument called "Curimbó", which is made of wood and animal skin. Cascudo (1972) interpreted that 
"curi" would have the meaning of wood and "imbo" of hollow, giving characteristic to this instrument that is used to propagate the sound, bringing the rhythm to Carimbó. Curimbó, according to Gabbay (2010, p. 2), is "the main artifact for holding meetings in terreiros, [...] characterized by its communicational and binding function around religious rituals, popular festivals and social gatherings".

Each region presents its particularity in dancing, as for example, in Soure, the capital of Marajó Island, and in Marapanim and Maracanã, coastal cities form the Salgado region, in which Figueiredo and Bogéa (2015, p. 83) describe, respectively, the "called Carimbó Pastoril" and "Carimbó Praieiro".

According to Neves (2013), the choreography is usually presented in pairs and in circles. It starts with a line of men and another of women; when the music starts, the men dance, addressing the women and clapping their hands, indicating an invitation to dance, they accept, starting the presentation; then the couples continually revolve around themselves and in the big circle.

With regard to clothing, the Carimbó dancers are always barefoot. Women wear long, round and patterned skirts, with light and smooth colors blouses, showing shoulders and belly, in addition to wearing bracelets and necklaces made from seeds from the Pará region and flowers in their hair. Men, generally, dance in white pants with rolled-up hems, a legacy of black culture; the blouses have strong colors, with the ends tied at the height of the navel, reminiscent of the clothing that the riverside population wore until the middle of the 20th century. On the head, the traditional straw hat, and a scarf wrapped around the neck (NEVES, 2013).

The accompaniment of the dance is done by two drums, ganzá, reco-reco, banjo, flute, maracas, afoxé and tambourines. However, there is also a more modern development of Carimbó, which emerged after the success of singer Pinduca, artistic name of Aurino Quirino Gonçalves. He was responsible for the national launch of Carimbó, with the inclusion of electric and wind instruments in traditional Carimbó, with special emphasis on the electric bass that, in the arrangements, makes a very original and characteristic line.

It was in the year 1970 that Carimbó music started to interest intellectuals and folklorists. However, it was not yet a music of urban consumption, that is, of the middle classes and of the cultural industry; it was more consumed by the popular, countryside and suburban sectors. Salles and Salles (1969, p. 259) points out that it was "the entertainment that most animates the population of this region", as it was present at all parties, whether they are private or in regional celebrations. 
The singer from Pará, Pinduca, is one of the main representatives of Carimbó music, as well as Mestre Verequete, who was the first to record Carimbó and put it to play in the halls. In 1971, he created the group "The Uirapuru of Amazon", which performed in several places, the main one being in Icoaraci, a district of Belém. (COSTA, 2011, p. 10).

And from that moment, Carimbó became known and seen throughout the world, leaving a little of its regional vision for a global view. And what has this globalization brought to Carimbó? Today, it is seen by many as entertainment, whose essential connotation is in the identity and memory formation of a nation, as well as the representation of a people, bringing in the dances (choreographies) and the clothes of its participants, the characteristics of Pará.

It was from the 1970s that Carimbó arrived in the city of Belém, being danced in bars, at concerts and social parties. Several groups and recordings from various LPs put Carimbó on television and radio. But it was in 1990 that Carimbó reached the media around the world, through many musical groups that were formed and, thus, became a trend in Brazilian musical rhythms. "Singers of earth" was a recording in which renowned regional singers (Pinduca, Nilson Chaves and Fafá de Belém) appeared in the regional media, publicizing Carimbó as a product of the cultural industry, giving more visibility and credibility to the rhythm.

On September 11, 2014, Carimbó was unanimously registered by the Cultural Heritage Advisory Council as Intangible Heritage of Brazil. A group of artists, researchers, cultural producers and the rubber stamp community in Para organized the "Campaign of Carimbó", which aimed, according to Figueiredo and Bogéa (2015, p. 90), "to consolidate the appreciation of Carimbó, mainly through post-registration actions, which perpetuate, after IPHAN's registration in 2014, the constant legitimation of this important cultural expresión."

So, the "traditional Carimbó" undergoes several changes and adaptations; the most noticeable was from curimbó, which is no longer lonely, as several instruments entered to compose the rhythm, becoming a "modern carimbó". Gabbay (2010) says that, even with all this growth, he still manages to remain faithful to his roots, and what really brings change is the political force, which always ends up pointing out the issue of the traditional and the modern.

And to be modern is to be constantly updated, always trying to compose the call, by Gabbay (2010), "contemporary cultural melting pot". Do not sing only Carimbó, but mix this rhythm with the other genres that are a trend in the world, always making it a hybrid component, which can be inserted in festivals, parties and artist presentations. 
A significant change was in the rhythm of Carimbó: it became faster and stopped being just a choreographic dance. At the beginning, the dancers demonstrate the basic steps and then perform the introduction of tourists in dance, giving the opportunity to experience. And, with that, tourism turned Carimbó into a job, as Figueiredo and Bogéa (2015, p. 88) points out: "thus, tourism transforms the playful into a component of a parafolkloric group, that is, a worker, which is a first reducing movement."

This reductive movement is due to the fact that Carimbó, now interpreted as a typical dance from Pará, leaves the community parties and it is easily found in the halls of hotels, tourist spots and festivals programmed by the government. Tourism modifies the playful, which previously had the rhythm as leisure, and now becomes a worker, dancing to earn money. In view of this, Figueiredo and Bogéa $(2015$, p. 85) affirm that "Tourism is the main niche in the performance of parafolkloric groups, in addition to presentations at events of organs official bodies of culture and tourism, such as the June festivals and the Círio de Nossa Senhora de Nazaré."

According to Figueiredo and Bogéa (2015, p. 88), "Carimbó then migrates to tourist ghettos, which are spaces and equipment created specifically for tourism". And this change is reported by the old residents, where Carimbó leaves homes and private parties (weddings, baptisms, birthdays) to perform in the parlor groups, at cultural events organized by the city.

According to Giffoni (1973), the word folklore is derived from the fusion of the word "folc" which in Anglo-Saxon dialects mean people, and "lore", in the sense of knowledge, that is, in the traditional sense of knowledge of people.

The work of folkloric dances in the Physical Education curriculum cannot be based only on the recognition of differences or treating them as exotic products from disqualified groups. What is being suggested is that each dance has its cultural marks (gestures, rhythms, additions, representatives, choreographies, etc.) transformed into an object of critical reading, experience and reflection.

\section{Sensory-Motor Development in Children}

For Wallon (1975), the primary means for the child is the social environment, without which human transformations are not possible. The social environment is the child's first reality and the beginning of all conscious education that the adult can offer. This view does not imply considering development as directly determined by the adult, but understanding that the child develops in the relationship of his plasticity, between his biological being and the social environment. In this sense, education is a necessity for children, as much as their food. 
According to Wallon (1975), man, as a human being, is the integration result of four functional sets: affectivity, motor act, cognition (intelligence) and person. Early in life, these sets are undifferentiated; however, with development, they assume specific functions and activities. Affection is characterized by emotional dispositions and feelings; the motor act by general body movement; cognition by structuring thought; and the person, due to the result of the integration of the three functional sets, constituting the unit of human being.

In the sensorimotor stage, the child makes an extensive and differentiated agreement between perceptions and movements. This relationship, in its simplest form, is the reflex act, that is, a certain excitation corresponds to a certain movement. The affective set offers the responsible functions for emotions and feelings. The motor assembly offers the possibility of displacing the body intime and space. And the cognitive set offers some functions that allows the acquisition and maintenance of knowledge through images, notions, ideas and representations. It is also what allows us to record and review the past, fix and analyze the present and project possible and imaginary futures.

\section{Physical Education and the Body Culture of the Movement}

In the 1980s, Physical Education was seen only as a physical activity, in which students should be submitted to activities whose main objective was to improve physical fitness, in addition to influencing behavior, shaping character.

According to Souza Junior, (2011), physical fitness was, for a long time, the fundamental criterion not only for the selection of content and for its sequential organization, but also for carrying out the evaluation. The legal document that expressed this clearly was Decree Law No. 69,450, of 1971 - edited, therefore, during the Military Dictatorship, post-1964.

It is important to note that during this period, the content of Physical Education at school was fundamentally based on corporal exercise through analytical exercises, runs, jumps, etc. That is, assuming, through these contents and forms, the characteristics worked in a military institution. And the teacher-student relationship took place directly, in which the teacher presented the exercises and the student should perform, without any kind of exchange of experiences.

Souza Junior (2011) affirm that, in the 1970s and 1990s, Physical Education made physical activity hegemonic geared towards sports. This happened due to the fact that, in public policies for the Physical Education and Sport sector, School Physical Education 
was conceived and integrated with the Brazilian sports system, having as one of its most important functions to promote sports initiation, in order to identify talents.

According to Caparroz (2007), in the 1980s, in the context of a broad social and political movement in favor of the democratization of Brazilian society, a movement was also created, within the Brazilian Physical Education community, called a renewing movement, which was characterized by promoting a strong criticism to the role attributed, until then, to Physical Education in the school curriculum. This movement unleashed the idea of Physical Education focused on sport, valuing the learning process and no longer the execution of an isolated technical gesture. And it is from there that a radical change occurs in the understanding of the content of the discipline.

Currently, the goal of Physical Education becomes the general plan of Integral Education. The content becomes an instrument to promote interpersonal relationships and facilitate the development of the child's nature, using varied forms of body movements, differentiating them from the stereotyped activities of high-level sport. Adapting, modifying, creating forms of movement are now the watchwords.

In Early Childhood Education, knowledge about body culture is developed, primarily, in an experiential way. At this time, Physical Education classes should provide a wide range of motor opportunities, in order to the student explore his ability to move, discover new body expressions, master his body in various situations, try motor actions with new implements and rhythms varied. The role of the teacher in this cycle will be to lead the student, when performing motor actions, understand its meaning and its forms of execution.

The children's school is, therefore, according to our understanding, a place of discoveries and expansion of individual, cultural, social and educational experiences, through the insertion of the child in environments other than the familiar (BASEI, 2008. p. 01). And these pedagogical practices need to dialogue with the cultural, playful and social elements that are part of the children daily lives and their families, thus consolidating socially referenced actions. Therefore, Physical Education can contribute to the effective program of Early Childhood Education, working with the child's development process and with the formation of the subject.

\section{Method}

The research presented in this article is a field invetigation of the Case Study type with a qualitative approach and a phenomenological approach. She was submitted to the ethics committee, in compliance with Resolution 196/96-CNS, which deals with research instruments, together with the Free and Informed Consent Form - TCLE and the 
Free and Informed Consent Form - TALE and the Authorization Term Use of Image, Testimony and / or Recording.

The research was carried out at a school in Belém (PA) in 2019, whose participants were: a teacher; six students in the kindergarten class, two female and four males, all three years old. Data collection was performed in the morning, once a week, lasting 45 minutes, over 2 months. The field diary contributed to the recording of the notes, to later obtain a better understanding of the students' behavior and development during the targeted activities. As the research took place during Physical Education classes, the school court was used for meetings with students. Twelve activities were carried out and each one was given a name and three were distributed permeeting. After four meetings, the activities were repeated and in all of them, we use the speaker and a computer to transmit the songs of Carimbó.

And to carry out the analysis of the results by the Data Triangulation, the indicators that were in constant dialogue with the related authors were used together with the object of the research study.

\section{Results and discussions}

In the first teacher interview, we tried to understand how she conducted her students in the classes and how they were in the affective, cognitive and motor issue. Thus, we knew the students, who would participate in the research a little more.

According to the teacher, affectivity, cognition and motor skills are always worked on in her classes, because these are aspects that students need to develop during the year. She says: "any activity that is done in class with them has at least one of these aspects being worked on" (interview conducted on March 17, 2019).

And when we asked the teacher about Carimbó, she confirmed that it is not within the content related to the kindergarten, which is her class. However, she works on the subject in the Folklore month and in the feast of Saint John: "In those moments, we focus more on the regional content. So, we show the dance costumes, and we take a few steps and we always work with the lyrics and with the interpretation" (interview held on March 17, 2019).

The teacher says that in relation to affective aspects, she develops a work through dialogue, called a "conversation circle". In this conversation, the students sit on the floor, together with her, in the shape of a circle; at that moment, their behavior is observed and, if there is any conflict, it is solved in the group. The teacher explains: "Because at that age, they have a lot of difficulty about sharing objects, sharing materials, so we emphasize respect for others; to space; to the differences and, mainly, to the attitude of 
apologizing" (Interview held on March 17, 2019). At this age, some children are still reluctant to apologize, so she puts a lot of emphasis on this action in that process.

For Wallon (1995), emotion is the exteriorization of affectivity, that is, its body expression. It is when the child establishes the first ties with the human world through the physical world. And the feeling corresponds to the representational expression of affectivity, not implying instant and direct relationships as in emotion.

Another activity carried out, which we worked with the affective aspect, was Follow de master"this time without the aid of the hula hoop, only with the sound box. During the song, we directed a step from Carimbó and they imitated; then, we passed the turn to one of the children and she took another step from Carimbó; and then, we repeat the movement until all have been the "master". This was an activity that involved the memory of the steps already worked in the previous class and the perception of their space during the dance. As for the Carimbó dance, Salles and Salles (1969, p. 261) describe it as "a dance that contains men and women in pairs, who dance freely and during the presentation, soloist choreographic configurations are formed".

According to the teacher "they really enjoyed the contact with Carimbó" (interview held on March 17, 2019), and this acceptance facilitated the work developed with them and their relationship as friends, bringing them closer and closer. During this activity, we reported only an impatience girl who not accepting that her colleagues repeated the steps she developed, cried. And the two friends, who repeated it, provoked the girl to cry more. Therefore, it was necessary to talk to them to improve the activity and reduce conflicts. Due the conversation, the activity spent a little more of the determined time, but, in the end, we reached the goal: to carry out different steps of Carimbó for each student.

The activity of the affective aspect that we call "Carimbó", Curimbó was used to tell its story and bring children closer to this important element for the construction of the Carimbo name and rhythm. So, we work, with the help of this element, dance and rhythm. They were excited to see the instrument, but because it was so heavy, they were unable to move and lift it off the ground. Everyone had the opportunity to sit on top and "play" a song in Curimbó. This contact with the instrument drew their attention, providing impeccable behavior, in the sense that there were no inappropriate attitudes during the activity.

Through the activity developed, Girl what to do with this round skirt inspired by a song by the singer from Pará, Lia Sophia, we used a Carimbó skirt, and placed the students around it, each holding a part. By the sound of the music, we played a plastic ball and, together, they moved the skirt until the ball fell into its opening, thus 
developing teamwork, so, they performed the dynamics to the sound of the theme song. The activity was very fun, and the children were delighted to see the Carimbó skirt. Before we put the ball in the middle of the skirt to do the job, we let them handle the piece a little to reduce anxiety. They were lifting the skirt for about 5 minutes, then we directed the activity.

When the ball was placed in the middle for the first time, they swung the skirt very hard and the ball came out of the piece, and one of the children had to pick it up. Not even on the first, second, third and fourth attempt did the ball pass through the hole. Two of the boys were just swinging for swinging their skirts, while the two girls and two boys quickly realized that they should swing slowly and together so that the ball reached the hole. As a result, the children who were trying to carry out the activity began to stress and fight with the two boys who were not collaborating in the best way. And one of the boys who had already understood the activity started to cry, both because the activity was not working and because of the friends who were not understanding. He even withdrew from the activity for a moment.

In another meeting with the children, we did the activity called Follow the Master, using a wooden instrument called maracas that the children built in the motor aspect activity. And this time, we created the movements with our instruments, slightly changing what we did in the previous month. At this time, we seek a little creativity from each student. It was relevant to see the children performing different and creative movements with the instruments, causing the other colleagues to repeat. We realized that, when we introduced the maracas in this activity, the conflicts decreased and the help of one colleague with the other was greater, because when it was time for one to carry out the movement, the colleagues kept showing the movements that could be made, thus guiding the friends. Even the student who was very tearful at the previous meeting, she managed to achieve her goals in a very pleasant way.

In another activity, when we took Curimbó again, the students were already familiar with the instrument, so much so that they arrived already sitting and wanting to drum. And we need, at that moment, to remove everyone from above in order to start the activity. One at a time had the opportunity to drum, and together we sang a Carimbó song. They only remembered the music of the singer from Pará, Dona Onete, "In the middle of the pitiú", that was worked on in the activity of the cognitive aspect, "Memorizing", in which we developed a small choreography.

When developing the activity "Girl, what to do with this round skirt?", we had a certain facility due to the students already knowing it. We managed to develop in the ten minutes we planned it. Children danced the music that was played, even with a task 
to be developed, taking full advantage of the activity, seeking to find the contribution of dancing to the development of affectivity and awakening in students, the feeling of respect for others, the control of their emotions in the face of conflicts and the expression of their feelings with the help of music.

According to Wallon (1995), the development of affectivity is related to the child's affected behaviors by the external / internal world. Thus, the teacher develops this aspect, through speech during the "conversation circle", in which she puts conflicts for students and talks with them, making them recognize wrong acts and attitudes and avoid repeating them.

We asked the teacher if any progress was noticed in the development of these students' affective aspects, and she reported: "I noticed a greater interaction and complicity between them" (interview held on March 17, 2019). In addition, during the research, the children became more talkative and more observant during the teacher's speech, presenting a longer concentration time.

Thus, according to Wallon (1995), the cognitive set offers a set of functions that allows the acquisition and maintenance of knowledge through images, notions, ideas and representations. It is also what allows us to record and review the past, fix and analyze the present and project possible and imaginary futures.

In continuity with the research activities, we carry out the so-called Rabbit Hole, which consists of spreading the hula hoops around the court space, each child with hers. To the sound of Carimbó's music, children must dance in the hula hoop space, and as soon as the music is interrupted, they must run to another hula hoop. Over time, the hula hoops will be removed and the child without hula hoops will leave the activity. We worked in this activity, the questions of losing, winning and respecting the colleague, without having to push anybody to enter the hula hoop.

We got a good understanding of the children when the activity was explained. There was a feeling of anxiety on the girls part to change hula hoops, so that they often ended up not dancing inside the hula hoop. The boys had a very significant participation in this activity, but two of them lost a lot of time when changing places, because they were not aware of the activity. One of the boys quickly understood the activity, so that he won the three times it was performed.

Continuing, another activity of the cognitive aspect was performed, called, "Memorizing". We chose a Carimbó song and, from it, we developed a choreography, that is, we combined and ordered steps to be done during the song. With this activity, we stimulate students' memory. According to Giffoni (1973), there are different and 
important values for working with folk dances at school. One of them is the mental value, which aims to develop the functions of attention, imagination, memory and reasoning.

The following activity, which we call Masters of Carimbó, presents to the children some elements and music characteristic of these singers and composers about our Carimbó, such as traditional songs of these musicians, elements of their dress and style of their dances, in order to obtain greater interactivity with the Carimbó culture. So, they used the instrument to play, in their own way, and we sang some songs by some Masters, so that they would already know. By showing some photos and videos of these Masters, we introduced the class to some of the characteristics of these musicians.

According to Wallon (2007), the development of the person as a complete human being does not occur in a linear and continuous way, but presents movements that imply integration, conflicts and alternations in the predominance of functional groups. With regard to affectivity and cognition, these sets take turns, in terms of prevalence, throughout the development stages.

The activity, Ah! How good it is to fish! which refers to the lyrics of Master Lucindo's songs, we work with a futsal net, which is usually placed in the goal posts, to simulate a large fishing net. We launched this net on the court, spread forty-four colored plastic fish and, to the sound of the music, students should pick up the fish that were in the network. Then, they should take them out of the net and count how many were caught by them and what their colors were, thus developing skills in counting and recognizing colors. We threw the net on the floor and placed the little fish spread out and everyone performed the activity together. At the signal of the music, they ran, stayed on top of the net, catching the fish. One of the girls caught her foot in the net a lot and fell several times, letting her little fish fall from her hands, allowing other children to capture them. After there were no more fish in the net, everyone went back to their seats to check how many had caught and what colors they were. Four children took almost the same amount of fish, but two other children took a much smaller amount. The two children who caught few fish were: the girl who curled up in the net and fell and a boy who could not put the fish in his arms because the toys slipped.

In the activity Masters of Carimbó held for the second time, it was used Curimbó again as a support to remember the songs sung by the Masters, we met at the previous meeting. And when one of the boys was sitting and playing in Curimbó, another boy went there and pushed him off the instrument, saying that it was his turn and that his friend had already played a lot. At that time, the activity needed a pause, to talk about this attitude and to help the child who fell. 
For Wallon (1975), education needs to respect the totality of personality and integrity of the child's evolution and learning processes, considering the student inserted in the lived context, directed towards the independence development of his autonomy.

Cognition is seen as part of the complete person, which can only be understood integrated with him, whose development occurs from the organic conditions of the species, and it is the result of the integration between his organism and the environment, and predominantly the social. Thus, development is conditioned both by organic maturation and by functional exercise, provided by the environment (WALLON, 1995).

We talked to the teacher about the children's behavior throughout the research, she said that "they always came back more euphoric, more talkative" (interview conducted on March 17, 2019), and they started to express themselves more during the other activities. The respect relationship between colleagues increased and, in relation to the development of affective, cognitive and motor aspects, she reported as "maturation" by the children. In this regard, for Wallon (1975), the teacher becomes a fundamental element of the systematized educational process, as he is the organizer of teaching centered on the integral development of the student's possibilities and skills.

For Wallon (1995), the motor aspects, such as running, jumping, throwing, grabbing and hitting are fundamental movements that must be learned before being combined with other skills, in order to become specialized motor skills. And the motor aspects, the teacher works inside the room and outdoors: "From tearing the paper, making a paper ball, making collage, their own painting and drawing, walking in a straight line and curved line" (interview conducted in 17 March 2019). She uses endless play and activities to develop this motor coordination in the child.

In the activity Exchange Exchange, which helps us to develop the aspect of running, laterality and jumping, we put children on one side of the court, inside the hula hoop space and one beside the other; on the sound of music, they must perform tasks, such as dancing, jumping, spinning, etc., inside their hula hoop; and as soon as the music is interrupted, they must run to the other hula hoop on the other side of the court. In this activity, we can also work on the students' reaction time as soon as the music stops.

As a second activity of the motor aspect, we carry out the activity called Building the instrument, with the help of small pet bottles and pebbles, we build recyclable maracas. There, the motor aspector was worked in the act of placing each pebble in the hole of the bottle and in the movement of shaking the created instrument, helping the fine motor coordination of the children. The nursery school is, therefore, according to our understanding, a place of discoveries and expansion of individual, cultural, social and 
educational experiences, through the insertion of the child in environments other than the familiar (BASEl, 2008).

To carry out the activity, we left the court and went to the school playground, where there were pebbles to put in the pet bottles during the construction of our maracas. The girls placed the stones with ease in the bottle, as they always looked for the smaller stones. The boys, on the other hand, did not take much note of the stones size; if the stone was too big, they would print more force when passing it through the hole in the bottle.

At meeting number three, we did the Puzzle activity, in which children experience the construction of the clothes used in Carimbó. A boy and girl made of cardboard are placed at one end of the court and the pieces of clothing are placed at the other side; at the sound of the whistle, the student must look in the jar for the clothes of Carimbó and go to the little cardboard doll to fit the right clothes, until the two dolls are arranged with the clothes of Carimbó; thus, it helps the child to recognize one of the elements of the Carimbó culture and, at the same time, working the race and fitting the pieces to the dolls.

During the activity, none of the children agreed on the complete combination of the Carimbó clothes of the dolls. However, what attracted the most attention was one of the girls who, despite every day experiencing Carimbó in their activities, did not fit any of the pieces of Carimbó's clothing. The other children put the doll with the Carimbó skirt, but with other blouses, and the boy with the flowered blouse, but with other shorts and pants.

According to Giffoni (1973), there are different and important values for working with folk dances at school, among them are corporeal value, which is a form of physical and complete exercise, improves circulatory and respiratory functions, contributes to agility and flexibility of movements; and moral value, which encourages and improves self-control, initiative, enthusiasm and a sense of order.

With that, we end the activities of the children motor aspects. We reveal the ways that Carimbó contributes to obtaining laterality, motor coordination (coarse and fine) and agility.

At the beginning, the teacher had already reported a certain difficulty of one of the boys and in the first activities we noticed a certain imbalance in the running act. When the activity called for running, he always fell, and the fact that the girls were showing a competitive feeling made him more nervous when running, making him lose his balance. So, we noticed, actually, he had falls during the entire activity. 
The development of these fundamental motor aspects is basic to children's motor development and motor education. For Wallon (1995), a wide variety of motor experiences provides children with a wealth of information on which to base their perception of themselves and the world around them.

When we talked to the teacher about the fact that they were working with Carimbó, if there was any comment from them on the subject in the classroom, she reported that they liked it very much, and they always came to the classroom talking about the activities carried out: "I rode like this, doing some dance steps or singing part of the songs" (interview held on March 17, 2019); and when the students were released to play, they remembered the games and played them on the playground.

For Wallon (2007), affective, cognitive and motor development have different rhythms according to the organic-social relationship expressed in each individual, and activities need to correspond to these rhythms, thus, the pace must be respected and not evaluated. Therefore, at the end of the internship, we will have a complete child, with its own possibilities and limitations.

\section{Final considerations}

Through the analysis of the six students in the kindergarten class and the questionnaires carried out with the teacher, the observations of the activities development and questionnaires made us identify the ways that Carimbó, while dancing, contributes to the development of affectivity in the student, how to: characterize the skills of Carimbó that can be used for cognitive development, in addition to revealing the ways that Carimbó contributes to motor coordination.

With this, we find the ways that Carimbó contributes to the sensory-motor development in Early Childhood Education students, specifically in the kidergarten of a private school in Belém of Pará, in Physical Education classes, through dance, the instruments construction, puzzle activities, running and capturing objects with the help of implements or not.

The immersion of Carimbó within Physical Education classes allowed us, in the affective aspect, through the dances developed in hula hoops; the reproduction of dance movements performed by students; from dancing to the sound of Curimbó and ways of handling the skirt to direct the ball in the hole, achieving respect for others, patience, control of emotions, waiting, increased interaction with colleagues and the development of dialogue between them. In the cognitive aspect, we achieve concentration, memorization and touch to create strategies that lead to a better development in the activity. And in the motor aspect, with the displacement of one hula hoop to the other, 
through the race; with the construction of instruments with PET bottles and the puzzle, we achieved coarse motor coordination; by placing the pebbles in the bottle and the clothes on the dolls, we develop fine motor coordination, thus, contributing to the sensorimotor development of each of them.

In this sense, the research reveals that the use of Carimbó, a characteristic rhythm of the northern region, is an element of these children culture, for the sensory-motor development, as well as the progress of activities, when the children returned to the classroom, talking about the pace and the activities developed that day. This encouraged the teacher to use this content to develop her classes and as a result, the kids were getting closer and more familiar with Carimbó.

During the execution of the research, we found some obstacles in its development, as for example, that our expectation was that the students would always be well, psychologically. However, over the weeks, some children showed impatience and stress during activities. These students arrived at school showing these behaviors.

With that, in the course of the instruments application, we already expected that children would not have the same behaviors, as well as they would not achieve the results together, since each one has their time and their individuality regarding learning and behavior. So, we assumed that it would not be easy, as we would have to be patient and work with children in different ways, even if the activities were the same. In this sense, we observed that some understand faster than others, and in the teacher's questionnaire detailed the behavior of each student, their particularities, difficulties and qualities.

The survey also signaled that the knowledge about Carimbó did not generate strangeness on the part of the children, even if contact between the research students is minimal on the subject. In addition, affective activities showed that students were able to control their emotions, acquired patience and developed better interaction with colleagues.

Cognitive activities showed us a development of concentration and memorization; motor activities improve students; motor activities give a motor domain corresponding to their age group. In this perspective, the practice of Carimbó rhythm is an instrument of development within the classes as a component to develop the skills proposed by BNCC, and can be used, as dance. Besides, it can be used as forms of activities, in games and plays, as it is a cultural characteristic component of the region of Pará.

\section{References}


BASEl, Andréia Paula. A Educação Física na Educação Infantil: a importância do movimentar-se e suas contribuições no desenvolvimento da criança. Revista Iberoamericana de Educación, v. 47, n. 3, p. 1-12, 2008.

BRASIL. BNCC - Base Nacional Comum Curricular. Proposta Preliminar Primeira Versão Revista. Brasília, DF, 2016.

CAPARROZ, F. E. Entre a educação física na escola e a educação física da escola. 3. ed. Campinas: Autores Associados, 2007.

CASCUDO, Luís da Câmara. Dicionário de folclore brasileiro. Brasília: Instituto Nacional do Livro, 1972.

COSTA, Tony Leão da. Carimbó e Brega: Indústria cultural e tradição na música popular do norte do Brasil. Revista Estudos Amazônicos, Belém v. VI, n. 1, p. 149 - 177, 2011.

FIGUEIREDO, Silvio Lima. BOGÉA, Eliana. Hibridismo cultural e atualização da cultura: o Carimbó do Brasil. Revista Resgate, Campinas, v. 23, n. 2, p. 81-92, 2015.

GABBAY, Marcello M. Representações sobre O Carimbó: Tradição X Modernidade. In: Anais do IX Congresso de Ciências da Comunicação na Região Norte - Intercom. Rio Branco: Intercom, 2010.

GIFFONI, Maria Amália Corrêa. Danças Folclóricas Brasileiras. 3. ed. São Paulo: Melhoramentos, 1973.

NEVES, Adriana Di Marco. A dança do Carimbó, 2013. Disponível em: <http://wikidanca.net/wiki/index.php/A_Dan\%C3\%A7a_do_Carimb\%C3\%B3>. Acesso em: 08 abr. 2018.

SALLES, Vicente, SALLES, Marena Isdebski. Carimbó: trabalho e lazer do caboclo. Revista Brasileira de Folclore, Rio de Janeiro, v. 9, n. 25, p. 257-282, set./ dez. 1969.

SOUZA JUNIOR, Marćlio et al. Coletivo de autores: a cultura corporal em questão. Rev. Bras. Ciênc. Esporte (Impr.) [online]. 2011, vol.33, n.2, pp.391-411. ISSN 0101-3289. https://doi.org/10.1590/S0101-32892011000200008.

SOUZA, Aparecida Ivonete Merenda. O professor PDE e os desafios da escola pública paranaense. v.2. Danças Folclóricas na Educação Física. Resgatando a Cultura Popular. 2011.

WALLON, Henri. A evolução psicológica da criança. São Paulo: Martins Fontes, 2007. WALLON, Henri. As origens do caráter da criança. São Paulo: Nova Alexandria, 1995. WALLON, Henri. Psicologia e Educação da Infância. Lisboa: Estampa, 1975. 


\section{arevisto Observatório}

\section{RESUMO:}

Este artigo destaca, o Carimbó como símbolo da cultura tradicional e identidade paraense, um instrumento para trabalhar a teoria de Wallon sobre o desenvolvimento sensóriomotor. Teve como problemática, conhecer a maneira que o Carimbó contribui para o desenvolvimento sensório-motor em alunos da Educação Infantil (maternal) nas aulas de Educação Física. A pesquisa qualitativa do tipo Estudo de Caso, utilizou a observação participativa e a entrevista aberta com uma professora e seis alunos. Para a análise dos dados, foi utilizada a Triangulação de Dados. Como resultados, compreendemos que o Carimbó viabilizou o desenvolvimento sensório-motor dos alunos, pois foi possível observar o desenvolvimento dos aspectos pesquisados.

PALAVRAS-CHAVE:

Carimbó:

Desenvolvimento Sensório-Motor; Educação Física.
e-ISSN n ${ }^{\circ} 2447-4266$

Palmas, v. 7, n. 1, p. 1-20, jan.-mar., 2021 http://dx.doi.org/10.20873/uft.2447-4266.2021v7n1a1en

\begin{abstract}
RESUMEN:
Este artículo destaca, el Carimbó como símbolo de la cultura tradicional e identidad de Pará, un instrumento para trabajar la teoria de Wallon sobre el desarrollo sensoriomotor. Problematizó conocer la manera como el Carimbó contribuye al desarrollo sensoriomotor en alumnos de la Educación Infantil (primer ciclo) en las clases de Educación Física. La investigación cualitativa de Estudios de Caso, utilizó la observación participativa y entrevista abierta con una maestra y seis alumnos. Para el análisis de datos, se utilizó la Triangulación de Datos. Como resultados, entendemos que Carimbó posibilitó el desarrollo sensoriomotor de los alumnos, pues fue posible observar el desarrollo de los aspectos investigados.
\end{abstract}

PALABRAS-CLAVES: Carimbó; Desarrollo Sensoriomotor; Educación Física. 